\title{
Trend of fall-related mortality among the elderly
}

\author{
Tendência de mortalidade por quedas em idosos \\ Tendencia de la mortalidad por caídas en los ancianos
}

How to cite this article:

Monteiro YCM, Vieira MAS, Vitorino PVO, Queiroz SJ, Policena GM, Souza ACS. Trend of fall-related mortality among the elderly. Rev Esc Enferm USP. 2021;55:e20200069. https://doi.org/10.1590/1980-220X-REEUSP-2020-0069

\author{
D Yara Cristina Martins Monteiro ${ }^{1}$ \\ D Maria Aparecida da Silva Vieira ${ }^{2}$ \\ D Priscila Valverde de Oliveira Vitorino ${ }^{2}$ \\ (D) Silvio José de Queiroz ${ }^{2}$ \\ (iD) Gabriela Moreira Policena ${ }^{3}$ \\ (D) Adenicia Custódia Silva e Souza² \\ ${ }^{1}$ Pontifícia Universidade Católica de Goiás, \\ Coordenação Regional de Educação de Goianésia, \\ GO, Brazil. \\ ${ }^{2}$ Pontifícia Universidade Católica de Goiás, Escola \\ de Ciências Sociais e da Saúde, Goiânia, GO, Brazil. \\ ${ }^{3}$ Universidade Federal de Goiás, Instituto \\ de Patologia Tropical e Saúde Pública, Goiânia, \\ GO, Brazil.
}

\begin{abstract}
Objective: To analyze the temporal trend of fall-related mortality in elderly in Brazil from 2008 to 2016. Method: Study of time series of rates of fall-related mortality according to CID-10 from 2008 to 2016. Data from the Mortality Information System on death registers of people $\geq 60$ living in Brazil were used. The specific rates of fall-related mortality among the elderly were calculated through the ratio between the number of deaths and the elderly population of that year and region. The populational information was obtained from the 2000 and 2010 censuses. The variation rate and temporal trend were obtained through linear regression $(p<0.05)$. Results: The fall-related deaths among the elderly aged $\geq 60$ amounted to 72,234 (31.2\%). Falls from the same level were the most frequent (53.8\%) and death rates in all ages ranged from 29.7 to 44.7 per 100,000 elders. Fall-related deaths increased with age. Conclusion: There was a growing trend of fall-related deaths among elderly in all age groups, an event which is avoidable through the adoption of preventive measures. The high rates and growing trend of fall-related deaths, as well as the aging of the Brazilian population, suggest that public policies for protecting the elderly must be prioritized.
\end{abstract}

\section{DESCRIPTORS}

Aged; Accidental Falls; Death; Time Series Studies; Public Health.
Corresponding author:

Adenicia Custódia Silva e Souza

Av. Universitária, 1440, Área IV, St. Universitário

74605-010 - Goiânia, GO, Brazil

adeniciafen@gmail.com
Received: 02/28/2020

Approved: 06/23/2021 


\section{INTRODUCTION}

Fall-related mortality among the elderly creates an economic, social, and psychological cost, representing a worldwide public health problem ${ }^{(1-3)}$. Falls entail high rates of hospitalization, functional disability, social isolation, and death, particularly in this age group ${ }^{(4-6)}$, and may lead to physical limitations with a higher level of dependence ${ }^{(7)}$.

Falls are leading causes of morbidity and mortality worldwide, imposing a burden for victims, their families, and society ${ }^{(2,6,8)}$. The costs associated to this event range from 731 to 1,186 dollars among elderly over 65 years old ${ }^{(6)}$. The World Health Organization (WHO) estimates that falls will be the 17th most frequent cause of death until 2030 in case prevention actions are not performed ${ }^{(9)}$.

In Brazil, only two studies investigated the national setting of hospitalization and the rates of fall-related mortality among the elderly ${ }^{(5,10)}$, registering an increase in deaths in recent years. Considering that there is a yearly expressive increase in the number of elders, who are exposed to the risk of falling, this study presents more recent data adding important evidence to the Brazilian context. In addition, it strengthens the discussion on the types of falls, enabling strategies with greater possibility of success in preventing this event, which is commonly avoidable, among this population.

The preoccupation with the prevention of fall-related deaths among the elderly brings new research questions which may provide subsidies to optimize planning further care for the elderly population by the health care network. Thus, conducting studies of trend analysis of fall-related deaths may contribute to a better elaboration of actions of promotion, prevention, and interventions. Therefore, this study had the objective of analyzing the rates and temporal trend of fall-related mortality among the elderly in Brazil from 2008 to 2016.

\section{METHOD}

\section{Type OF Study}

Time series study performed with secondary data of the National System of Mortality Information (Sistema Nacional de Informação sobre Mortalidade - SIM) of the database DATASUS, by the Brazilian Ministry of Health.

\section{Population}

The population of the study was constituted of people aged 60 or older with residency in Brazil and death register in SIM. The data were collected in SIM/DATSUS and its source were death certificates (DC) from 2008 to 2016. The information was collected from a public database of the Ministry of Health and its use is exempt from approval by an ethics committee.

Data by the Brazilian Institute of Geography and Statistics (Instituto Brasileiro de Geografia e EstatísticaIBGE) was used to obtain populational information on elders $\geq 60$ years old living in the federative units, 26 states and the federal district, in accordance with the
2000 and 2010 censuses. The population in 2008 and 2016 was estimated using the interpolation method, calculated by the Ministry of Health and available on a public domain website.

\section{Data Source}

Fall-related deaths were selected in SIM per basic cause, following the International Classification of Diseases (ICD-10), chapter XX, codes W00 to W19. The mortality data were extracted directly from the SIM.

\section{Study Variables}

The variables of interest which might contribute to the classification and analysis of data were date of death, date of birth, code of the municipality of residency and occurrence, sex, age, marital status, site of occurrence, and ICD-10 codes.

\section{Data Analysis and Treatment}

The data were downloaded from the SIM database and after their extraction they were converted to a stata data file (DTA) to enable an analysis through Data Analysis and Statistical Software (STATA), version 12.

Initially, the percentage of fall-related deaths based on the sociodemographic categories and the variation from 2008 to 2016 were calculated. The rate of fall-related mortality among the elderly were calculated through the ratio between the number of fall-related deaths and the total population aged 60 or older living in each region in the same period multiplied by 100,000 . The specific rate of fall-related mortality was also calculated for the age groups 60-69, $70-79$ and $\geq 80$ years old. The populational information was obtained from the censuses performed in 2000 and 2010.

In all cases, the supposition of linear evolution throughout time was observed to be a possible assumption. Due to this, for trend analysis, linear regression models were estimated. Subsequently, modeling was performed, considering the rates of fall-related mortality as dependent variables $(\mathrm{Y})$ and the year of death as an independent variable $(\mathrm{X})$.

The simple linear regression model has revealed a normal distribution. After obtaining the models, the trend (growing, decreasing, or stationary) was estimated for the mortality rates. The results of $\mathrm{R}^{2}$ measure the explanatory percentage of the model in relation to the response variable Y. The $\beta \mathrm{c}$. The latter describes the inclination of the line and represents the quantity of mean increase in $Y$ for the moment of an X unit. Significant trends were those whose estimated model obtained a $\mathrm{p}<0.05$ significance. Coefficient, their 95\% confidence intervals, and respective $\mathrm{p}$-values were also presented

\section{RESULTS}

From 2008 to 2016, 231,878 deaths of elderly aged 60 or older due to external causes were registered in SIM. Out of these, $72,234(31.2 \%)$ were due to falls, as shown in the flowchart for the selection of registers of fall-related deaths (Figure 1). 
The variation of the basic cause of death according to ICD-10 has shown that there was a $28.9 \%$ reduction in "unspecified falls" (W19). The highest proportion of fallrelated deaths were for "falls on same level" (53.8\%), with an increase of $31.7 \%$ (W01/W18) (Table 1).

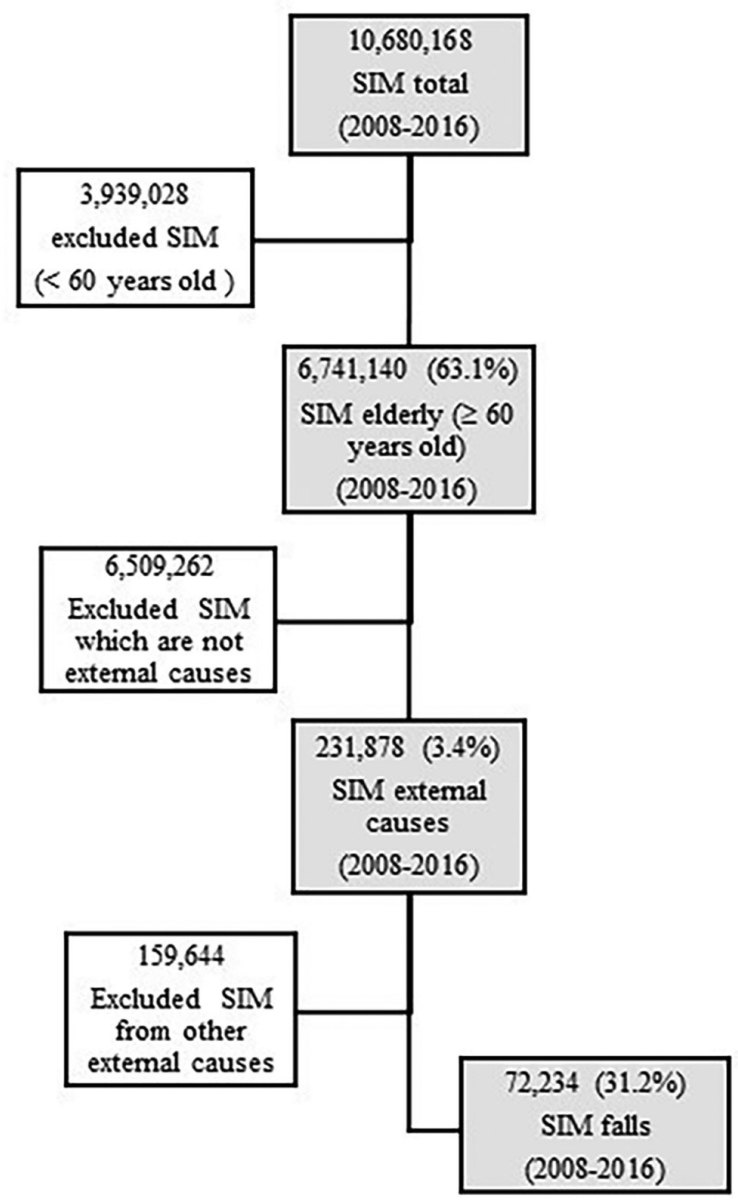

Figure 1 - Sample selection flowchart - Brazil, 2008-2016. Source: Sistema de Informação sobre Mortalidade (SIM)/DATASUS.
In the assessed period, there were 72,234 fall-related deaths and an increase in the number of deaths each year. An increase in the percentage with aging, which was higher among women who had no partner and lived in the Southeast region, was observed. The highest percentages of fall-related deaths took place at the hospital (Table 2).

Table 3 presents the rates of fall-related mortality, showing variations among the regions. There was an increase in the number of fall-related deaths in the assessed period in all states and all age groups. This increase was also observed with aging and was higher for elderly who were 80 or older in all regions. In the North and Northeast regions, the variation from 60 to 69 years was higher when compared with the age group from 70 to 79 years. Considering all the regions in Brazil, there was a yearly increase in fall-related deaths in all age groups, which was higher in the age group 80 years old or older. The highest percentage variations in the age group over 80 years old between 2008 and 2016 was observed in the regions North and Center-west.

There is an increasing trend in fall-related mortality in most regions and age groups. In the Center-west and North regions, the trend is stationary in the age groups from 60 to 69 years old and from 70 to 79 years old. In the Southeast region, it is so from 60 to 69 years old (Table 4).

\section{DISCUSSION}

This study presents national data on mortality rates due to falls in elderly in Brazil from 2008 to 2016 and performs a temporal analysis which shows an increase in the trend of fall-related deaths per region and age group.

In the studied period, there was a growth in the rates of fall-related mortality among elderly in all age groups as age increased. These rates are higher than those found in a regional study conducted in $\mathrm{Brazil}^{(4)}$, in $\mathrm{Spain}^{(6)}$, and in the United States ${ }^{(8)}$.

The highest rates of fall-related deaths in the age group of 80 years or older are related to aging, which is an

Table 1 - Frequency of fall-related mortality among the elderly and percentage variation after basic cause of death according to ICD-10 - Brazil, 2008-2016.

\begin{tabular}{|c|c|c|c|c|c|c|c|}
\hline \multirow{2}{*}{ ICD-10 } & \multicolumn{2}{|c|}{2008} & \multicolumn{2}{|c|}{2016} & \multicolumn{2}{|c|}{ Total (2008-2016) } & \multirow{2}{*}{$\stackrel{\%}{\text { Variation }^{\mathrm{a}}}$} \\
\hline & $\mathbf{n}$ & $\%$ & $\mathbf{n}$ & $\%$ & $\mathbf{n}$ & $\%$ & \\
\hline Falls on same level - W01/W18 & 2418 & 44.8 & 6476 & 59.0 & 38857 & 53.8 & 31.7 \\
\hline Unspecified falls - W19 & 2129 & 39.5 & 3079 & 28.1 & 23158 & 32.1 & -28.9 \\
\hline Fall on and from stairs and steps - W10 & 198 & 3.7 & 309 & 2.8 & 2486 & 3.4 & -24.3 \\
\hline Falls from, out of or through building or structure - W13 & 211 & 3.9 & 300 & 2.7 & 2272 & 3.1 & -30.8 \\
\hline Falls from bed - W06 & 158 & 2.9 & 306 & 2.8 & 1942 & 2.7 & -3.4 \\
\hline Other falls from one level to another - W17 & 117 & 2.2 & 249 & 2.3 & 1573 & 2.2 & 4.5 \\
\hline Other $^{b}$ & 161 & 3.0 & 250 & 2.3 & 1946 & 2.7 & -23.3 \\
\hline Total & 5392 & 100.0 & 10969 & 100.0 & 72234 & 100.0 & - \\
\hline
\end{tabular}

a Percentage shift (\% of variation): (2016 rate -2008 rate)/2008 rate $\times 100$.

${ }^{b}$ Includes ICD W04 - Fall while being carried or supported by other persons; W03 - Other fall on same level due to collision with another person; W09 - Fall on and from playground equipment; W16 - Jump or diving into water, causing other injury apart from drowning and submersion; W00 - Fall on same level due to ice and snow; W02 - Fall involving ice-skates, skis, roller-skates or skateboards; W07 - Fall from chair; W14 - Fall from tree; W11- Fall on and from ladder; W12 - Fall on and from scaffolding; W08 - Fall from other furniture; W05 - Fall from non-moving wheelchair, nonmotorized scooter and motorized mobility scooter; W15 - Fall from cliff.

Source: Sistema de Informações sobre mortalidade (SIM)/DATASUS. 
Table 2 - Fall-related mortality among the elderly after sociodemographic characteristics per year in Brazil - 2008-2016 ( $\mathrm{n}=72,234)$.

\begin{tabular}{|c|c|c|c|c|c|c|c|c|c|c|c|c|c|c|c|c|c|c|c|c|}
\hline \multirow{2}{*}{ Variables } & \multicolumn{2}{|c|}{2008} & \multicolumn{2}{|c|}{2009} & \multicolumn{2}{|c|}{2010} & \multicolumn{2}{|c|}{2011} & \multicolumn{2}{|c|}{2012} & \multicolumn{2}{|c|}{2013} & \multicolumn{2}{|c|}{2014} & \multicolumn{2}{|c|}{2015} & \multicolumn{2}{|c|}{2016} & \multicolumn{2}{|c|}{ Total } \\
\hline & $\mathbf{n}$ & $\%$ & $n$ & $\%$ & $\mathbf{n}$ & $\%$ & $n$ & $\%$ & $\mathbf{n}$ & $\%$ & $\mathbf{n}$ & $\%$ & $\mathbf{n}$ & $\%$ & $\mathbf{n}$ & $\%$ & $\mathbf{n}$ & $\%$ & $\mathbf{n}$ & $\%$ \\
\hline $\begin{array}{l}\text { Total fall- } \\
\text { related } \\
\text { deaths }\end{array}$ & 5392 & - & 5671 & - & 6802 & - & 7116 & - & 7844 & - & 8775 & - & 9539 & - & 10126 & - & 10969 & - & 72234 & - \\
\hline \multicolumn{21}{|l|}{$\begin{array}{l}\text { Age range } \\
\text { (years) }\end{array}$} \\
\hline 60 to 69 & 1004 & 18.6 & 1023 & 18.0 & 1203 & 17.7 & 1221 & 17.1 & 1358 & 17.3 & 1482 & 16.9 & 1562 & 16.4 & 1652 & 16.3 & 1801 & 16.4 & 12306 & 17.0 \\
\hline 70 to 79 & 1554 & 28.8 & 1576 & 27.8 & 1828 & 26.9 & 1869 & 26.3 & 2020 & 25.8 & 2244 & 25.6 & 2420 & 25.4 & 2583 & 25.5 & 2729 & 24.9 & 18823 & 26.1 \\
\hline$\geq 80$ & 2834 & 52.6 & 3072 & 54.2 & 3771 & 55.4 & 4026 & 56.6 & 4466 & 56.9 & 5049 & 57.5 & 5557 & 58.2 & 5891 & 58.2 & 6439 & 58.7 & 41105 & 56.9 \\
\hline \multicolumn{21}{|l|}{ Sex } \\
\hline Male & 2688 & 49.9 & 2759 & 48.7 & 3382 & 49.7 & 3505 & 49.3 & 3711 & 47.3 & 4172 & 47.5 & 4476 & 46.9 & 4771 & 47.1 & 5275 & 48.1 & 34739 & 48.0 \\
\hline Female & 2703 & 50.1 & 2912 & 51.3 & 3420 & 50.3 & 3610 & 50.7 & 4133 & 52.7 & 4603 & 52.5 & 5060 & 53.0 & 5353 & 52.9 & 5693 & 51.9 & 37487 & 51.9 \\
\hline Unreported & 1 & 0.0 & 0 & 0.0 & 0 & 0.0 & 1 & 0.0 & 0 & 0.0 & 0 & 0.0 & 3 & 0.1 & 2 & 0.0 & 1 & 0.0 & 8 & 0.1 \\
\hline \multicolumn{21}{|l|}{$\begin{array}{l}\text { Marital } \\
\text { status }\end{array}$} \\
\hline $\begin{array}{l}\text { Without } \\
\text { partner }\end{array}$ & 3163 & 58.7 & 3488 & 61.5 & 4190 & 61.6 & 4243 & 59.6 & 4657 & 59.4 & 5160 & 58.8 & 5735 & 60.1 & 6110 & 60.3 & 6521 & 59.5 & 43267 & 59.9 \\
\hline $\begin{array}{l}\text { With } \\
\text { partner }\end{array}$ & 1920 & 35.6 & 1902 & 33.5 & 2273 & 33.4 & 2367 & 33.3 & 2557 & 32.6 & 2885 & 32.9 & 3084 & 32.3 & 3312 & 32.7 & 3637 & 33.1 & 23937 & 33.1 \\
\hline Unreported & 309 & 5.7 & 281 & 5.0 & 339 & 5.0 & 506 & 7.1 & 630 & 8.0 & 730 & 8.3 & 720 & 7.6 & 704 & 7.0 & 811 & 7.4 & 5030 & 7.0 \\
\hline \multicolumn{21}{|l|}{$\begin{array}{l}\text { Site of } \\
\text { occurrence }\end{array}$} \\
\hline Hospital & 4601 & 85.3 & 4929 & 86.9 & 5962 & 87.7 & 6273 & 88.2 & 6975 & 88.9 & 7745 & 88.3 & 8457 & 88.7 & 8979 & 88.7 & 9787 & 89.2 & 63708 & 88.3 \\
\hline $\begin{array}{l}\text { Not the } \\
\text { hospital }\end{array}$ & 782 & 14.5 & 734 & 12.9 & 833 & 12.2 & 837 & 11.8 & 866 & 11.1 & 1020 & 11.6 & 1078 & 11.3 & 1141 & 11.3 & 1178 & 10.8 & 8469 & 11.7 \\
\hline Unreported & 9 & 0.2 & 8 & 0.2 & 7 & 0.1 & 6 & 0.0 & 3 & 0.0 & 10 & 0.1 & 4 & 0.0 & 6 & 0.0 & 4 & 0.0 & 57 & 0.0 \\
\hline \multicolumn{21}{|l|}{$\begin{array}{l}\text { Region of } \\
\text { residency }\end{array}$} \\
\hline South & 952 & 17.6 & 948 & 16.8 & 1130 & 16.7 & 1284 & 18.1 & 1347 & 17.2 & 1591 & 18.1 & 1784 & 18.7 & 1938 & 19.1 & 2224 & 20.3 & 13198 & 18.3 \\
\hline Northeast & 898 & 16.6 & 921 & 16.2 & 1076 & 15.8 & 1259 & 17.7 & 1409 & 18.0 & 1488 & 17.0 & 1733 & 18.2 & 1843 & 18.2 & 2112 & 19.3 & 12739 & 17.6 \\
\hline Southeast & 2915 & 54.1 & 3028 & 53.4 & 3722 & 54.7 & 3722 & 52.3 & 4118 & 52.5 & 4566 & 52.0 & 4853 & 50.9 & 5115 & 50.5 & 5192 & 47.3 & 37231 & 51.6 \\
\hline $\begin{array}{l}\text { Center- } \\
\text { west }\end{array}$ & 462 & 8.6 & 568 & 10.0 & 633 & 9.3 & 579 & 8.1 & 678 & 8.6 & 818 & 9.3 & 853 & 8.9 & 857 & 8.5 & 1012 & 9.2 & 6460 & 8.9 \\
\hline North & 165 & 3.1 & 206 & 3.6 & 241 & 3.5 & 272 & 3.8 & 292 & 3.7 & 312 & 3.6 & 316 & 3.3 & 373 & 3.7 & 429 & 3.9 & 2606 & 3.6 \\
\hline
\end{tabular}

Source: Sistema de Informações sobre Mortalidade (SIM)/DATASUS.

independent risk factor for falls ${ }^{(11,12)}$, as well as depression, incontinence, pain ${ }^{(13)}$, to being a female, having low income ${ }^{(14)}$, comorbidities, worse performance in equilibrium tests ${ }^{(13,14)}$ and multimorbidity, which leads to the use of polypharmacy ${ }^{(2)}$.

There was also a reduction in the rate of fall-related mortality among elderly in ICD-10 W19, "Unspecified falls", probably due to improvements in mortality information systems, a result of investments for qualifying health surveillance services ${ }^{(15)}$. A study on deaths due to poorly defined causes, conducted with data from the SIM of 2010, has shown that $9.3 \%$ of deaths due to external causes were reclassified to defined causes. This reclassification was more frequent in the Center-west and Northeast regions ${ }^{(15)}$.

The percentage of deaths of elders due to the basic cause "fall on the same level" was high in this study, with a growing variation when compared to the other studies, which had a negative variation and are compatible with the risk factors included in the literature ${ }^{(11,14)}$.

The results also suggest a higher frequency of fall-related deaths among women with no partner. These women probably fall more frequently as a consequence of using a higher dose and variety of medication ${ }^{(16-18)}$ and presenting equilibrium problems ${ }^{(13,16)}$ and higher social vulnerability ${ }^{(19)}$. The fact that they live alone exposes these women to a higher risk of falling due to having no help with some daily chores which are considered a risk for this age group.

In this study, the analysis of the trend of fall-related deaths in elderly over 80 years old has increased in all of Brazil, regardless of region. However, the Northeast and South regions are emphasized to present an increase in fall trend among all age groups. Regional disparities regarding inequities in health and healthcare cultures possibly influence the access to services in different regions of Brazil. In the Northeast region, this probably occurred due to an increase 
Table 3 - Mortality rate due to falls among elderly $(100,000)$ and percentage variation per age group and regions - Brazil, $2008-2016$.

\begin{tabular}{|c|c|c|c|c|c|c|c|c|c|c|c|}
\hline \multirow{2}{*}{ Age group (years) } & \multirow{2}{*}{ Region } & \multicolumn{9}{|c|}{ Rate per 100,000 citizens } & \multirow{2}{*}{$\begin{array}{c}\text { Variation } \\
\quad(\%)\end{array}$} \\
\hline & & 2008 & 2009 & 2010 & 2011 & 2012 & 2013 & 2014 & 2015 & 2016 & \\
\hline 60 to 69 & \multirow{4}{*}{$\mathrm{BR}$} & 9.9 & 9.7 & 11.0 & 10.7 & 11.3 & 11.8 & 11.9 & 12.1 & 12.7 & 28.3 \\
\hline 70 to 79 & & 27.7 & 27.3 & 30.7 & 30.5 & 31.9 & 34.4 & 35.9 & 37.0 & 37.6 & 35.7 \\
\hline$\geq 80$ & & 116.0 & 120.0 & 141.0 & 144.0 & 153.0 & 166.0 & 175.0 & 178.0 & 186.0 & 60.3 \\
\hline All ages & & 29.7 & 30.1 & 34.7 & 34.9 & 37.0 & 39.7 & 41.5 & 42.3 & 44.7 & 50.5 \\
\hline 60 to 69 & \multirow{4}{*}{$\mathrm{CW}$} & 11.2 & 10.3 & 9.8 & 11.1 & 12.1 & 10.8 & 12.6 & 10.7 & 14.8 & 32.1 \\
\hline 70 to 79 & & 31.6 & 39.4 & 43.3 & 30.4 & 33.8 & 45.3 & 43.6 & 40.7 & 54.6 & 72.8 \\
\hline$\geq 80$ & & 175.0 & 207.0 & 236.0 & 197.0 & 213.0 & 258.0 & 265.0 & 260.0 & 341.0 & 94.9 \\
\hline All ages & & 35.3 & 40.8 & 45.0 & 37.8 & 41.2 & 49.2 & 50.7 & 48.3 & 63.6 & 80.2 \\
\hline 60 to 69 & \multirow{4}{*}{ NE } & 6.0 & 6.2 & 6.6 & 7.0 & 7.7 & 8.7 & 9.1 & 8.7 & 10.8 & 80.0 \\
\hline 70 to 79 & & 16.2 & 15.8 & 16.6 & 20.9 & 21.4 & 21.9 & 23.2 & 26.0 & 28.8 & 77.8 \\
\hline$\geq 80$ & & 75.7 & 75.5 & 90.6 & 101.0 & 113.0 & 113.0 & 134.0 & 137.0 & 145.0 & 91.5 \\
\hline All ages & & 19.1 & 19.1 & 21.6 & 24.6 & 26.7 & 27.3 & 30.9 & 31.8 & 35.3 & 84.8 \\
\hline 60 to 69 & \multirow{4}{*}{$\mathrm{N}$} & 6.5 & 8.2 & 9.6 & 8.2 & 8.9 & 9.6 & 8.3 & 8.8 & 9.9 & 52.3 \\
\hline 70 to 79 & & 20.3 & 17.7 & 24.3 & 26.1 & 24.1 & 23.2 & 24.4 & 26.3 & 29.4 & 44.8 \\
\hline$\geq 80$ & & 77.6 & 108.0 & 107.0 & 128.0 & 136.0 & 139.0 & 135.0 & 158.0 & 167.0 & 115.2 \\
\hline All ages & & 18.3 & 22.0 & 24.7 & 26.6 & 27.3 & 27.8 & 26.9 & 30.3 & 33.2 & 81.4 \\
\hline 60 to 69 & \multirow{4}{*}{ SE } & 12.1 & 11.8 & 13.9 & 12.9 & 13.6 & 13.9 & 13.2 & 14.2 & 13.7 & 13.2 \\
\hline 70 to 79 & & 32.6 & 31.6 & 36.7 & 34.4 & 36.7 & 40.1 & 40.1 & 41.2 & 38.7 & 18.7 \\
\hline$\geq 80$ & & 126.0 & 128.0 & 151.0 & 148.0 & 158.0 & 168.0 & 176.0 & 173.0 & 172.0 & 36.1 \\
\hline All ages & & 34.2 & 34.1 & 40.3 & 38.7 & 41.0 & 43.6 & 44.4 & 44.9 & 43.7 & 27.8 \\
\hline 60 to 69 & \multirow{3}{*}{ S } & 10.4 & 9.6 & 10.1 & 10.3 & 10.9 & 11.7 & 13.3 & 12.6 & 12.3 & 18.3 \\
\hline 70 to 79 & & 32.6 & 31.3 & 33.0 & 35.4 & 36.2 & 36.8 & 44.0 & 43.5 & 43.5 & 33.4 \\
\hline$\geq 80$ & & 149.0 & 149.0 & 172.0 & 189.0 & 190.0 & 221.0 & 215.0 & 232.0 & 244.0 & 63.8 \\
\hline All ages & & 34.8 & 34.1 & 38.1 & 41.3 & 42.3 & 47.2 & 49.7 & 51.5 & 53.2 & 52.9 \\
\hline
\end{tabular}

a Percentage shift (\% of variation): (2016 rate -2008 rate)/2008 rate $\times 100$. BR: Brazil; CW: Center-West; NE: Northeast; N: North; SE: Southeast; S: South. Source: Sistema de Informações sobre Mortalidade (SIM)/DATASUS.

in elder population with reduced income and financial dependence on the younger population ${ }^{(20)}$. Remarkably, the Center-west, North, and Southeast regions presented a stationary trend in rates of fall-related mortality. This is possibly explained by the fact that these are data of a younger age group (60 to 79 years old), which presents better equilibrium and more preserved muscle force.

These results are consistent with data from the Netherlands ${ }^{(2)}$ and the United States ${ }^{(8)}$, which have also found a higher variation of deaths among older elderly from 2000 to 2016. Different data were found in Spain ${ }^{(21)}$, presenting an increasing trend in fall-related deaths from 2000 to 2015 in people aged 75 to 84 , although with no difference between this group and that of people aged 85 or older. Trend variation in these studies is related to differences among countries, both concerning demographic composition (immigrants), quality of life, daily activity customs, and elderly lifespan.

There is a global trend of increase in fall-related mortality among elders over $80^{(11,16,22)}$, since they now live longer and are more independent, which increases the risk of falling ${ }^{(2)}$.
Also, many of these elders live in high social vulnerability areas and are physically fragile ${ }^{(19)}$.

The growing trend in fall-related deaths among the elderly in Brazil, as shown in this study, and the knowledge of internal ${ }^{(2,12-13)}$ and external ${ }^{(11,14)}$ causes leading to these falls represent an alert to public health and health professionals. Prevention programs may decrease the rates of falls among the elderly in this age group, the number of hospitalizations, and the search for high complexity services, in addition to reducing public health expenses ${ }^{(23)}$.

Finally, strategies must be discussed, planned, and implemented by health professionals in an interprofessional and collaborative way, particularly those related to comorbidity prevention, reduction of polypharmacy, and regular physical activity focused on muscle strengthening and postural equilibrium, which may prevent falls. Adjustments in the domestic environment are also necessary since the main type of occurrence is "falls on the same level".

Dissemination and adoption of simple measures in the elders' houses which may prevent falls in this environment 
Table 4 - Trend of fall-related mortality among the elderly per age group and regions - Brazil, 2008-2016.

\begin{tabular}{|c|c|c|c|c|c|}
\hline Age group (years) & Region & $\mathbf{R}^{2}$ & $\begin{array}{l}\text { Regression coefficient }(\beta 1) \\
(95 \% \mathrm{Cl} \text { of } \beta 1)\end{array}$ & $\mathbf{p}$ & Trend \\
\hline 60 to 69 & \multirow{4}{*}{ Brazil } & 0.93 & $0.35(0.271-0.438)$ & $<0.001$ & $\uparrow$ \\
\hline 70 to 79 & & 0.96 & $1.38(1.145-1.620)$ & $<0.001$ & $\uparrow$ \\
\hline$\geq 80$ & & 0.98 & $9.10(7.847-10.349)$ & $<0.001$ & $\uparrow$ \\
\hline All ages & & 0.98 & $1.92(1.675-2.157)$ & $<0.001$ & $\uparrow$ \\
\hline 60 to 69 & \multirow{4}{*}{ Center-west } & 0.40 & $0.35(-0.130-0.826)$ & 0.129 & - \\
\hline 70 to 79 & & 0.44 & $1.86(0.141-3.572)$ & 0.038 & - \\
\hline$\geq 80$ & & 0.76 & $15.76(7.203-24.313)$ & 0.003 & $\uparrow$ \\
\hline All ages & & 0.72 & $2.64(1.032-4.250)$ & 0.006 & - \\
\hline 60 to 69 & \multirow{4}{*}{ Northeast } & 0.92 & $0.56(0.374-0.739)$ & $<0.001$ & $\uparrow$ \\
\hline 70 to 79 & & 0.94 & $1.59(1.202-1.970)$ & $<0.001$ & $\uparrow$ \\
\hline$\geq 80$ & & 0.97 & 9.35 (8.133-10.569) & $<0.001$ & $\uparrow$ \\
\hline All ages & & 0.98 & $2.07(1.771-2.368)$ & $<0.001$ & $\uparrow$ \\
\hline 60 to 69 & \multirow{4}{*}{ North } & 0.39 & $0.24(-0.045-0.519)$ & 0.088 & - \\
\hline 70 to 79 & & 0.63 & $0.99(0.390-1.593)$ & 0.006 & - \\
\hline$\geq 80$ & & 0.91 & $9.57(6.747-12.392)$ & $<0.001$ & $\uparrow$ \\
\hline All ages & & 0.89 & $1.50(1.021-1.981)$ & $<0.001$ & $\uparrow$ \\
\hline 60 to 69 & \multirow{4}{*}{ Southeast } & 0.52 & $0.22(0.038-0.401)$ & 0.024 & - \\
\hline 70 to 79 & & 0.76 & $1.09(0.497-1.692)$ & 0.003 & $\uparrow$ \\
\hline$\geq 80$ & & 0.87 & $6.47(4.020-8.926)$ & $<0.001$ & $\uparrow$ \\
\hline All ages & & 0.84 & $1.39(0.787-1.995)$ & 0.001 & $\uparrow$ \\
\hline 60 to 69 & \multirow{4}{*}{ South } & 0.76 & $0.41(0.189-0.624)$ & 0.003 & $\uparrow$ \\
\hline 70 to 79 & & 0.88 & $1.73(1.184-2.268)$ & $<0.001$ & $\uparrow$ \\
\hline$\geq 80$ & & 0.96 & $12.50(10.882-14.117)$ & $<0.001$ & $\uparrow$ \\
\hline All ages & & 0.98 & $2.58(2.184-2.978)$ & $<0.001$ & $\uparrow$ \\
\hline
\end{tabular}

Source: Sistema de Informações sobre Mortalidade (SIM)/DATASUS $\uparrow$ Increasing; - Stationary.

are also considered important. Creating support networks coordinated by the Basic Healthcare Network, encompassing their community and neighborhood, is a perspective which must be considered and implemented to support the elderly, who live increasingly alone.

The limitations of this study are related to its underreported, secondary data. However, the main advantage of this study is its large population, which shows a worrying and growing situation of fall-related deaths among the elderly, which requires professional, family, community, and public interventions to be prevented.

\section{CONCLUSION}

The temporal trend analysis of fall-related mortality among the elderly in Brazil from 2008 to 2016 showed a growing trend in deaths among the elderly in all age groups, increasing with age. However, these falls are avoidable with the adoption of preventive measures.

Considering the high rates of fall-related death shown in this study and the fast aging of the Brazilian population, elderly protection public policies must be prioritized and strengthened, aiming at the reduction of fall-related mortality in this population.

\section{RESUMO}

Objetivo: Analisar a tendência temporal da mortalidade por quedas em idosos no Brasil de 2008 a 2016. Método: Estudo de série temporal das taxas de mortalidade por quedas segundo CID-10 de 2008 a 2016. Utilizaram-se dados de registro de óbito de residentes no Brasil, com idade $\geq 60$ anos, constantes no Sistema de Informação sobre Mortalidade. Foram calculadas as taxas de mortalidade específica por quedas em idosos por meio da razão entre o número de óbitos e a população idosa residente naquele ano e região. As informações populacionais foram obtidas dos censos de 2000 e 2010 . A taxa de variação e a tendência temporal foram obtidas por regressão linear $(p<0,05)$. Resultados: Foram identificados $72.234(31,2 \%)$ óbitos por quedas em idosos $\geq 60$ anos. Quedas no mesmo nível foram as mais frequentes $(53,8 \%)$ e as taxas de óbito em todas as idades variaram de 29,7 a 44,7 por 100.000 idosos. Os óbitos por queda aumentaram conforme a idade. Conclusão: Houve tendência crescente de óbitos por quedas em idosos em todas as faixas etárias, 
eventos evitáveis com a adoção de medidas preventivas. As elevadas taxas e a tendência de aumento dos óbitos por queda, bem como o envelhecimento da população brasileira, sugerem que políticas públicas de proteção aos idosos devem ser priorizadas.

\section{DESCRITORES}

Idoso; Acidentes por Quedas; Morte; Estudos de Séries Temporais; Saúde Pública.

\section{RESUMEN}

Objetivo: Analizar la tendencia temporal de la mortalidad por caídas en ancianos en Brasil de 2008 a 2016. Método: Estudio de serie temporal de las tasas de mortalidad por caídas según CIE-10 de 2008 a 2016. Se utilizaron datos de los registros de defunción de residentes en Brasil con edad $\geq 60$ años disponibles en el Sistema de Información sobre Mortalidad. Las tasas de mortalidad específica por caídas en los ancianos se calcularon mediante el cociente entre el número de muertes y la población de ancianos por año y región. La información poblacional se obtuvo de los censos de 2000 y 2010. La tasa de variación y la tendencia temporal se obtuvieron mediante regresión lineal ( $p<0,05)$. Resultados: Se identificaron $72.234(31,2 \%)$ muertes por caídas en ancianos $\geq 60$ años. Las caídas desde el mismo nivel fueron las más frecuentes $(53,8 \%)$ y las tasas de mortalidad en todas las edades oscilaron entre 29,7 y 44,7 por cada 100.000 ancianos. Las muertes por caídas aumentaron según la edad. Conclusión: Hubo una tendencia al aumento de las muertes por caídas en los ancianos en todos los grupos de edad, un evento evitable con la adopción de medidas preventivas. Las elevadas tasas y la tendencia al aumento de las muertes por caída, así como el envejecimiento de la población brasileña, sugieren que las políticas públicas de protección a los ancianos deben ser prioritarias.

\section{DESCRIPTORES}

Anciano; Accidentes por Caídas; Muerte; Estudios de Series Temporales; Salud Pública.

\section{REFERENCES}

1. Morsch P, Myskiw M, Myskiw JC. Falls' problematization and risk factors identification through older adults' narrative. Cien Saude Colet. 2016;21(11):3565-74. DOI: https://dx.doi.org/10.1590/1413-812320152111.06782016.

2. Hartholt KA, van Beeck EF, van der Cammen TJM. Mortality from falls in Dutch adults 80 years and older, 2000-2016. JAMA. 2018;319(13):1380-2. DOI: https://dx.doi.org/10.1001/jama.2018.1444.

3. Cheng P, Wang L, Ning P, Yin P, Schwebel DC, Liu J, et al. Unintentional falls mortality in China, 2006-2016. JoGH. 2019;9(1):010603. DOI: https://dx.doi.org/10.7189/jogh.09.010603.

4. Antes DL, Schneider IJC, d'Orsi E. Mortality caused by accidental falls among the elderly: a time series analysis. Revista Brasileira de Geriatria e Gerontologia. 2015;18(4):769-78. DOI: https://dx.doi.org/10.1590/1809-9823.2015.14202.

5. Stolt LROG, Kolisch DV, Tanaka C, Cardoso MRA, Schmitt ACB. Increase in fall-related hospitalization, mortality, and lethality among older adults in Brazil. Rev Saude Publica. 2020;54:76. DOI: https://dx.doi.org/10.11606/s1518-8787.2020054001691.

6. Verma SK, Willetts JL, Corns HL, Marucci-Wellman HR, Lombardi DA, Courtney TK. Falls and fall-related injuries among communitydwelling adults in the United States. PLoS One. 2016;11(3):e0150939. DOI: https://dx.doi.org/10.1371/journal.pone.0150939.

7. Luzia MF, Prates CG, Bombardelli CF, Adorna JB, Moura GMSS. Characteristics of damage falls in hospitalized patients. Rev Gaucha Enferm. 2019;40(n. esp):e20180307. DOI: https://dx.doi.org/10.1590/1983-1447.2019.20180307.

8. Hartholt KA, Lee R, Burns ER, van Beeck EF. Mortality from falls among US adults aged 75 years or older, 2000-2016. JAMA. 2019;321(21):2131-3. DOI: https://dx.doi.org/10.1001/jama.2019.4185.

9. World Health Organization [Internet]. WHO Global Health Estimates. 2014 [cited 2018 Mar 22]. Available from: https://www.who.int/ data/global-health-estimates.

10. Abreu D, Novaes ES, Oliveira RR, Mathias TAF, Marcon SS. Fall-related admission and mortality in older adults in Brazil: trend analysis. Cien Saude Colet. 2018;23(4):1131-41. DOI: https://dx.doi.org/10.1590/1413-81232018234.09962016.

11. Pereira SG, Santos CBD, Doring M, Portella MR. Prevalence of household falls in long-lived adults and association with extrinsic factors. Rev Lat Am Enfermagem. 2017;25:e2900. DOI: https://dx.doi.org/10.1590/1518-8345.1646.2900.

12. Bhattacharya B, Maung A, Schuster K, Davis KA. The older they are the harder they fall: injury patterns and outcomes by age after ground level falls. Injury. 2016;47(9):1955-9. DOI: https://dx.doi.org/10.1016/j.injury.2016.06.019.

13. Gale CR, Westbury LD, Cooper C, Dennison EM. Risk factors for incident falls in older men and women: the English longitudinal study of ageing. BMC Geriatr. 2018;18(1):117. DOI: https://dx.doi.org/10.1186/s12877-018-0806-3.

14. Gazibara T, Kurtagic I, Kisic-Tepavcevic D, Nurkovic S, Kovacevic N, Gazibara T, et al. Falls, risk factors and fear of falling among persons older than 65 years of age. Psychogeriatrics. 2017;17(4):215-23. DOI: https://dx.doi.org/10.1111/psyg.12217.

15. França E, Teixeira R, Ishitani L, Duncan BB, Cortez-Escalante JJ, Morais OL Neto, et al. III-defined causes of death in Brazil: a redistribution method based on the investigation of such causes. Rev Saude Publica. 2014;48(4):671-81. DOI: https://dx.doi.org/10.1590/S00348910.2014048005146.

16. Musich S, Wang SS, Ruiz J, Hawkins K, Wicker E. Falls-related drug use and risk of falls among older adults: a study in a US medicare population. Drugs Aging. 2017;34(7):555-65. DOI: https://dx.doi.org/10.1007/s40266-017-0470-x.

17. Falci DM, Mambrini JVM, Castro-Costa E, Firmo JOA, Lima-Costa MF, Loyola Filho Al. Use of psychoactive drugs predicts functional disability among older adults. Rev Saude Publica. 2019;53:21. DOI: https://dx.doi.org/10.11606/s1518-8787.2019053000675.

18. Garcia BP, Gonzalez SM, Munoz AMC, Anton-Solanas I, Caballero VG, Vela RJ. Risk of drug-related falls among noninstitutionalized older adults. Rev Esc Enferm USP. 2018;52:e03319. DOI: https://dx.doi.org/10.1590/s1980-220x2017012603319.

19. Bolina AF, Rodrigues RAP, Tavares DMS, Haas VJ. Factors associated with the social, individual and programmatic vulnerability of older adults living at home. Rev Esc Enferm USP. 2019;53:e03429. DOI: https://dx.doi.org/http://dx.doi.org/10.1590/S1980-220X2017050103429. 
20. Nakatani-Macedo CD, Fiuza-Moura FK, Ferreira CR, da Camara MRG. Projeções do envelhecimento da população do nordeste de 2000 a 2030 e suas implicações na renda. Revista Nexos Econômicos. 2016;10(1):107-33. DOI: https://dx.doi.org/10.9771/1516-9022rene. v10i1.13187.

21. Padron-Monedero A, Damian J, Pilar Martin M, Fernandez-Cuenca R. Mortality trends for accidental falls in older people in Spain, 2000-2015. BMC Geriatr. 2017;17(1):276. DOI: https://dx.doi.org/10.1186/s12877-017-0670-6.

22. Burns E, Kakara R. Deaths from falls among persons aged $\geq 65$ years - United States, 2007-2016. MMWR Morb Mortal Wkly Rep. 2018;67(18):509-14. DOI: https://dx.doi.org/10.15585/mmwr.mm6718a1.

23. Johnston YA, Bergen G, Bauer M, Parker EM, Wentworth L, McFadden M, et al. Implementation of the Stopping Elderly Accidents, Deaths, and Injuries initiative in primary care: an outcome evaluation. Gerontologist. 2019;59(6):1182-91. DOI: https://dx.doi.org/10.1093/geront/ gny 101.

The Goiás Research Foundation (Fundação de Amparo à Pesquisa do Estado de Goiás - FAPEG) funded this study through a Master's program scholarship. 